\title{
Novelties in the roadside flora of Moravia and Silesia (Czech Republic) - 1. Spergularia media
}

Petr Kocián

Novelties in the roadside flora of Moravia and Silesia (Czech Republic) - 1. Spergularia media. - Acta Mus. Siles. Sci. Natur., 64: 263-267, 2015.

\begin{abstract}
The paper reports on a find of the short-lived perennial halophyte Spergularia media on the D1 motorway in NE Moravia, which is the second known record from motorways in the Czech Republic. Possible ways of introduction are shortly discussed.
\end{abstract}

Key words: Spergularia media, motorways, floristics, Czech Republic.

\section{Introduction}

Spergularia media (L.) C. Presl is a short-lived perennial halophyte with its main distribution in the western Eurasian coastal and inland saline habitats (Friedrich 1979) and has been introduced in North and South America, East Asia and Australia (Hartman \& Rabeler 2005). In the Czech Republic, the native populations of $S$. media are confined to a few inland saline sites in southern Moravia (Ducháček \& Kúr, in prep.) and the species is classified as a critically threatened taxon $(\mathrm{C} 1)$ in the Red List of vascular plants of the Czech Republic (Grulich 2012).

\section{Occurrence along roads}

The first occurrence of Spergularia media along roadsides associated with application of de-icing salt during winter was registered in the USA (Reznicek 1980) and Great Britain (Scott \& Davison 1982) in the 1970s and 1980s. In Central Europe, S. media is occasionally found along roads too, but the records are more recent. In Austria, Hohla \& Melzer (2003) registered it on the A1 motorway at Großram rest place in Lower Austria in 2002 and remarked that it had not previously been known from German or Austrian motorways. Adler et al. (2008) observed some localities in road verges along the A1 motorway and its entries and exits in Vienna. In the Czech Republic, only one locality of $S$. media on the motorway network has been known to date (Kúr, Štech \& Ducháček, unpubl.). Spergularia media is also present on motorways in north-western Hungary and western Slovakia (G. Király \& P. Eliáš, pers. comm.).

\section{Materials and methods}

The study area covers the regions Moravia and Silesia in the eastern part of the Czech Republic. Nomenclature of taxa follows the Checklist of vascular plants of the Czech Republic (Danihelka et al. 2012). Regional phytogeographical division follows Skalický (1988). Mapping grids correspond to the Central European floristic mapping network (Slavík 1971). Coordinates in WGS-84 and elevations are derived from the internet map application www.mapy.cz. Herbarium abbreviations are according to Thiers (2015). The map was created with QGIS application. 

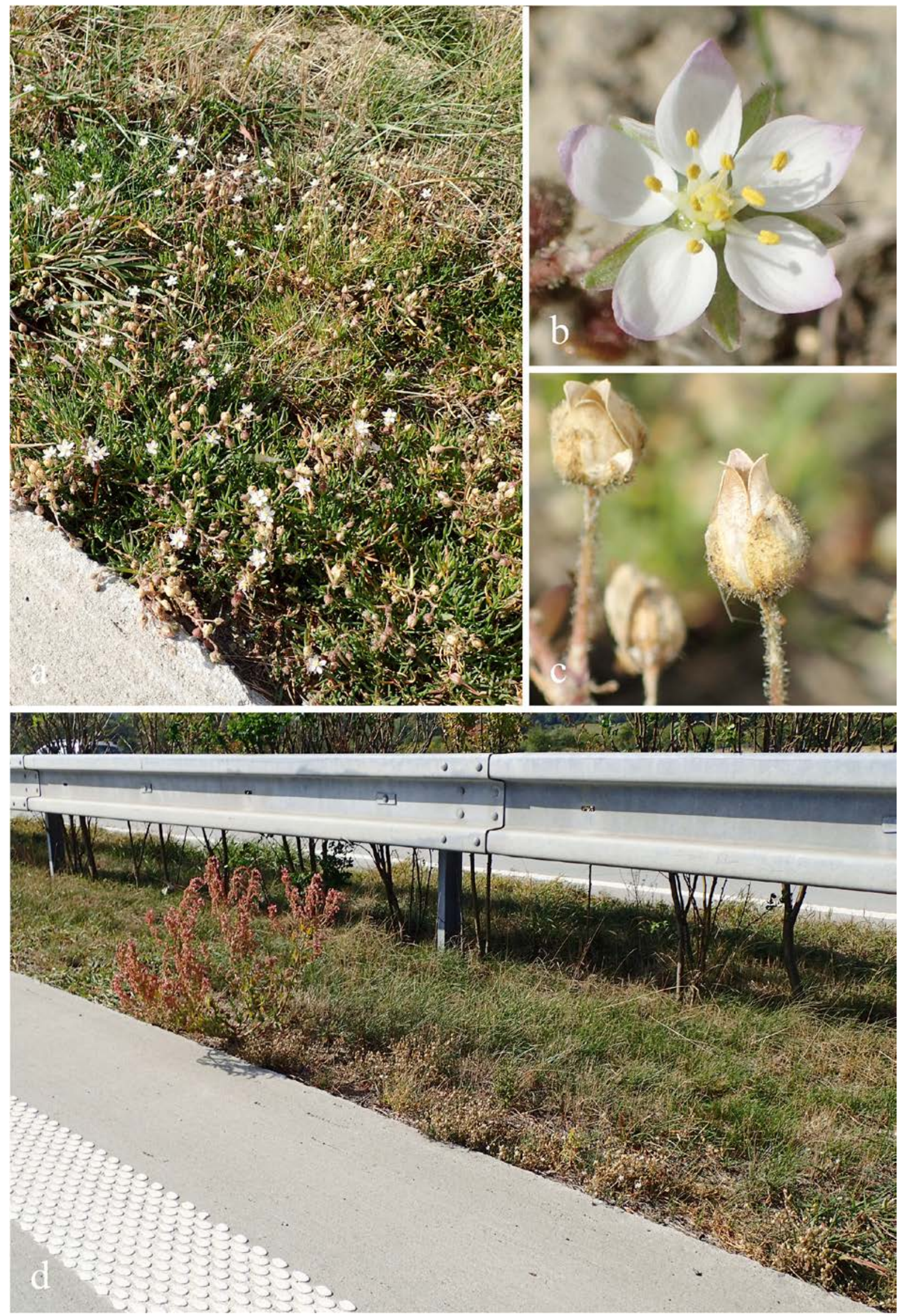

Fig 1: Spergularia media: a - stand, $\mathrm{b}$ - flower (detail), c - fruit (detail), d - habitat: central reservation, D1 motorway in the direction of Ostrava, 317.0-317.5 km (3. X. 2015). Photo by Petr Kocián. 


\section{Results}

Spergularia media was found on the D1 motorway in the direction of Ostrava between the 317.0 and 317.5 distance markers in northern Moravia (Fig. 1). The population of around 50 individuals was growing in a 2-metre long strip in the central reservation and the following noteworthy species were recorded to grow scattered nearby: Dittrichia graveolens (ca. 25 individuals), Atriplex micrantha (ca. 10 individuals) and Spergularia marina (ca. 100 individuals). Also around 10 individual plants of $S$. media were scattered in a 50-metre long strip from the main population towards Ostrava (in the traffic direction). The size of the population suggests that $S$. media has been established at the site for some time (this section of the motorway was opened in 2009) and is spreading slowly by air turbulences caused by road traffic.

\section{Locality}

\section{D1 motorway}

76a. Moravská brána vlastní, 6372d, Hynčice (distr. Nový Jičín): D1 motorway in the direction of Ostrava, 317.0-317.5 km, central reservation, GPS 49 $37^{\prime} 23.26^{\prime \prime} \mathrm{N}, 17^{\circ} 49^{\prime} 15.55^{\prime \prime} \mathrm{E}, 318 \mathrm{~m}$ a.s.l., ca. 60 individuals (3. X. 2015 leg. P. Kocián, herb. BRNU, FMM, NJM, PR).

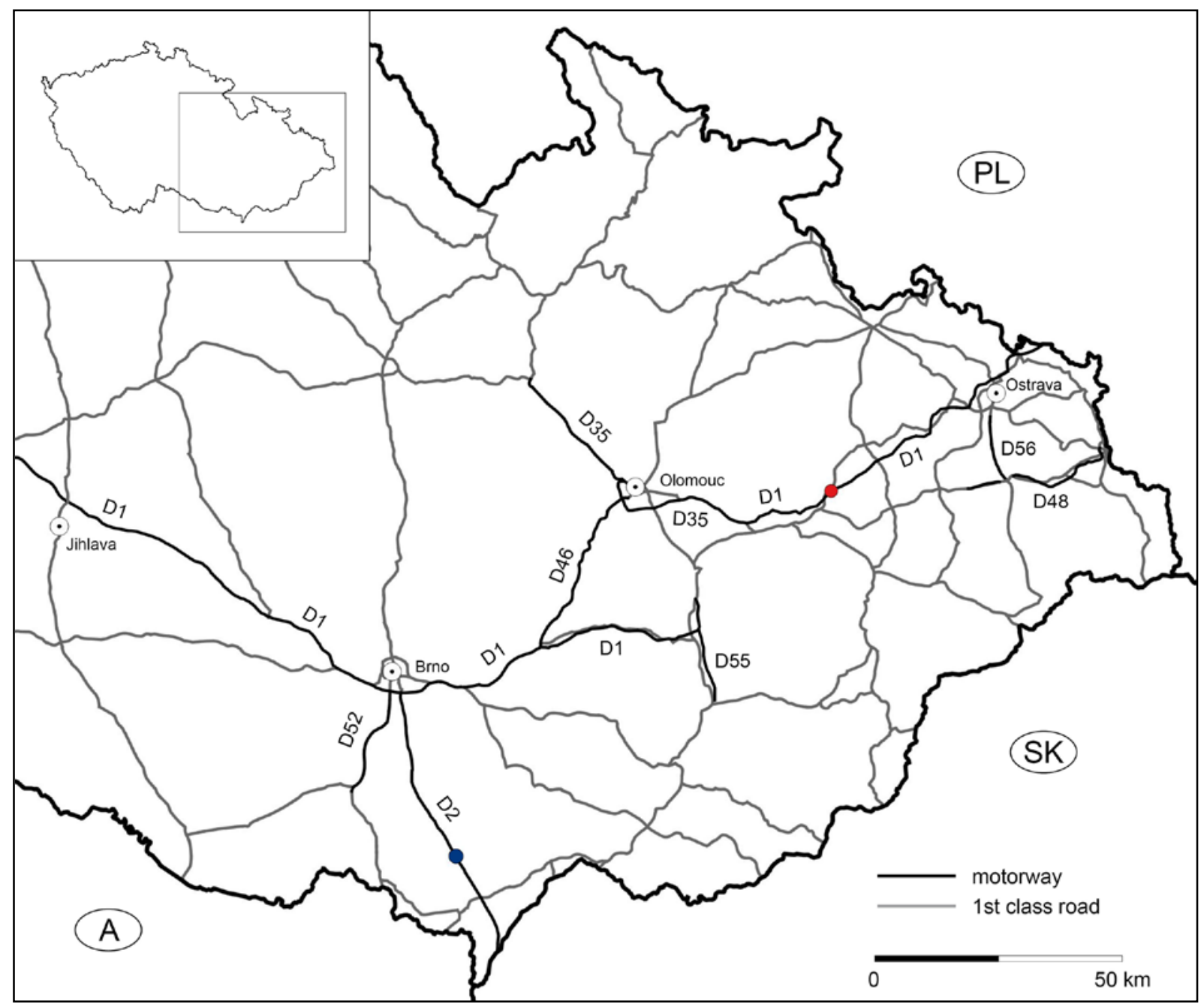

Fig 2: Distribution of Spergularia media on motorways in Moravia and Silesia. Red dot - the new locality on the D1 motorway (2015), blue dot - the locality on the D2 motorway found by M. Štech and P. Kúr in 2008. 


\section{Discussion}

The presented locality is only the second known record of Spergularia media on the Czech motorway network (Fig. 2). The first motorway locality was discovered on the D2 motorway in the direction of Bratislava between the 37.5 and 38.0 distance markers by M. Štech and P. Kúr in 2008 and later confirmed in 2014 (P. Kúr, pers. comm.). Several explanations on how $S$. media was introduced to motorways in Moravia are possible. (1) The propagules are of western origin (from motorways in Austria, Great Britain or from the original natural sites in Western Europe) and were accidentally introduced into the Czech Republic by intense international road transport, as the localities of $S$. media were found along motorway lanes which are used by traffic heading from Western Europe towards Slovakia in the case of the D2 motorway and from Western Europe/Austria towards Poland in the case of the D1 motorway. (2) The source of propagules could be the Pannonian region, where S. media occurs in natural inland saline habitats and is also present on motorways in northwestern Hungary and western Slovakia. On the D1 motorway, S. media was found along motorway lane which is used by traffic heading from Hungary and Slovakia towards Poland. (3) The D2 motorway locality (in southern Moravia) is relatively close to the original natural localities of the species (relics of inland saline sites), where the species occurred in the past and still persists, although rarely, to this day. The propagules of $S$. media could have originated from these southern Moravian inland saline sites and then been transported by vehicles to the new locality on the D1 motorway in northern Moravia. A detailed investigation into population genetics might be necessary to solve the problem of the origin of $S$. media populations on Czech motorways.

So far, there are just two known sites of Spergularia media on the Czech motorway network. This is in contrast with $S$. marina, which is quite common along motorways in the Czech Republic (Kúr \& Ducháček, unpubl.). Similarly, Scott \& Davison (1982) found that $S$. media was expanding slowly on the roads of north-eastern England, which was in marked contrast to $S$. marina. It could be a result of differences in life form, habitat preferences and also type of seeds between the two species. While the annual $S$. marina has light seeds, the short-lived perennial $S$. media has comparatively heavier seeds and is a species of more stable habitats. This might be a reason for slower expansion of the latter species, as is suggested in Scott \& Davison (1982).

Acknowledgements: I am grateful to P. Kúr for detailed information on his find of Spergularia media on the D2 motorway and G. Király and P. Eliáš for valuable information on their recent records of S. media along Hungarian and Slovak motorways.

\section{References}

Adler W., Mrkvicka A.Ch. \& Fischer M.A. (2008): Nachträge zur „Flora Wiens“ (III). - Neilreichia 5: 173180.

Danihelka J., Chrtek J. jun. \& Kaplan Z. (2012): Checklist of vascular plants of the Czech Republic. Preslia 84: 647-811.

Friedrich H.C. (1979): Familie Caryophyllaceae. pp. 763-1182. In: Reichinger K.H. (ed.): Illustrierte Flora von Mitteleuropa. Band 3. Teil 2. Verlag Paul Parey, Berlin \& Hamburg.

Grulich V. (2012): Red List of vascular plants of the Czech Republic: 3rd edition. - Preslia 84: 631-645.

Hartman R.L. \& Rabeler K.R. (2005): Spergularia (Persoon) J. Presl \& C. Presl. pp. 16-23. In: Flora of North America Editorial Committee (ed.): Flora of North America North of Mexico, Vol. 5: Magnoliophyta: Caryophyllidae, part 2. Oxford University Press, New York \& Oxford.

Hohla M. \& Melzer H. (2003): Floristisches von den Autobahnen der Bundesländer Salzburg, Oberösterreich, Niederösterreich und Burgenland. - Linzer Biol. Beitr. 35: 1307-1326. 
Reznicek A.A. (1980): Halophytes along a Michigan Roadside with Comments on the Occurrence of Halophytes in Michigan. - The Michigan Botanist 19: 23-30.

Scott N.E. \& Davison A.W. (1982): De-icing salt and the invasion of road verges by maritime plants. Watsonia 14: 41-52.

Skalický V. (1988): Regionálně fytogeografické členění. pp. 103-121. In: Hejný S. \& Slavík B. (eds): Květena České socialistické republiky. Vol. 1. Academia, Praha.

Slavík B. (1971): Metodika sít'ového mapování ve vztahu k připravovanému fytogeografickému atlasu ČSR. Zpr. Čs. Bot. Společ. 6: 55-62.

Thiers B. (2015): Index Herbariorum: A global directory of public herbaria and associated staff. New York Botanical Garden's Virtual Herbarium [online]. [cit. 1. 11. 2015]. Available from: http://sciweb.nybg.org/science2/IndexHerbariorum.asp.

Author's address: Petr Kocián, Nerudova 5, CZ-74101 Nový Jičín, Czech Republic.

E-mail: petr.kocian@kvetenacr.cz 